\title{
The flight feather moult pattern of the bearded vulture (Gypaetus barbatus)
}

\author{
Iñigo Zuberogoitia ${ }^{1}$ Juan Antonio $\mathrm{Gil}^{2} \cdot \mathrm{José}^{\text {Enrique Martínez }}{ }^{3} \cdot$ \\ Birgit Erni $^{4} \cdot$ Bakartxo Aniz $^{5}$ - Pascual López-López ${ }^{6}$
}

Received: 27 February 2015/Revised: 15 June 2015 / Accepted: 29 June 2015 / Published online: 14 July 2015

(C) Dt. Ornithologen-Gesellschaft e.V. 2015

\begin{abstract}
Moult is an extremely time-consuming and energy-demanding task for large birds. In addition, there is a trade-off between the time devoted to moulting and that invested in other activities such as breeding and/or territory exploration. Moreover, it takes a long time to grow a long feather in large birds, and large birds that need to fly while moulting cannot tolerate large gaps in the wing, but only one or two simultaneously growing feathers. As a consequence, large birds take several years to complete a full moult cycle, and they resume the moult process during suboptimal conditions. A clear example of this pattern is the Bearded Vulture (Gypaetus barbatus), which needs 2-3 years for changing all flight feathers. Here we describe the sequence, extent, and timing of moult of 124 Bearded Vultures in detail for the first time. We found that extent and timing of flight feather moult was different between age classes. Subadults (from 3rd to 5th calendar year)
\end{abstract}

Communicated by F. Bairlein.

Iñigo Zuberogoitia

zuberogoitia@icarus.es

1 Estudios Medioambientales Icarus S.L. C/San Vicente, 8. $6^{\text {a }}$ Planta, Dpto 8, Edificio Albia I, 48001 Bilbao, Bizkaia, Spain

2 Fundación para la Conservación del Quebrantahuesos, Plaza San Pedro Nolasco 1, 4u F, 50001 Zaragoza, Spain

3 Bonellís Eagle Study and Conservation Group, Apdo, 4009, 30080 Murcia, Spain

4 Department of Statistical Sciences, Centre for Statistics in Ecology, Environment and Conservation, University of Cape Town, Rondebosch 7701, South Africa

5 Pl Dra Juana García Orcoyen 5, 31012 Pamplona, Spain

6 Vertebrates Zoology Research Group, University of Alicante, Apdo. 99, 03080 Alicante, Spain started moult, on average, in early March, whereas adults only started moult, on average, in late April, possibly due to breeding requirements. Second calendar year individuals delayed onset of moult until the middle of May. In general, the moult lasted until November, and although adults started to moult later than subadults, they moulted more feathers. Subadults needed 3 years for moulting all flight feathers, whereas adults normally completed it in 2 years.

Keywords Bearded Vulture - Gypaetus barbatus - Moult sequence $\cdot$ Underhill-Zucchini model

\section{Zusammenfassung}

\section{Die Flugfedermauser beim Bartgeier}

Die Mauser ist ein extrem zeit- und energieaufwändiger Vorgang für große Vögel. Darüber hinaus gibt es einen Konflikt zwischen der Zeit, die für die Mauser aufgebracht wird und derjenigen, die in andere Aktivitäten investiert werden kann, so wie Brüten oder territoriale Exploration. Außerdem braucht das Wachstum einer langen Feder bei großen Vögeln lange; und große Vögel, die darauf angewiesen sind während der Mauser zu fliegen, können sich keine größeren Lücken in den Flügeln leisten, sondern nur ein oder zwei gleichzeitig nachwachsende Federn. Als Konsequenz braucht es mehrere Jahre, bis große Vögel einen vollen Mauserzyklus vollendet haben, und sie nehmen die Mauser unter suboptimalen Bedingungen wieder auf. Ein deutliches Beispiel für dieses Muster ist der Bartgeier (Gypaetus barbatus), der zwei bis drei Jahre braucht für einen kompletten Wechsel seiner Flugfedern. Hier beschreiben wir zum ersten Mal im Detail die Abfolge, das Ausmaß und das Timing der Mauser von 124 Bartgeiern. Wir fanden, dass Ausmaß und Timing der 
Flugfedermauser sich zwischen Altersklassen unterschied. Subadulte (vom dritten bis fünften Kalenderjahr) begannen die Mauser, im Durchschnitt, im frühen März, während die Mauser der Adulten im Durchschnitt erst im späten April begann, möglicherweise aufgrund von Zwängen im Zusammenhang mit der Brut. Individuen im zweiten Kalenderjahr verzögerten den Beginn der Mauser bis Mitte Mai. Generell dauerte die Mauser bis November, und obwohl Adulte mit der Mauser später begannen als Subadulte, mauserten sie mehr Federn. Subadulte brauchten drei Jahre zur Mauser sämtlicher Flugfedern, während dagegen Adulte normalerweise in zwei Jahren fertig waren.

\section{Introduction}

Large birds take a long time to complete a full cycle of lifehistory stages. Normally, each stage requires high amounts of energy that determine mutually exclusive activities (e.g. breeding, migration, and flight feather moult, Hedenström 2006). In birds, the time required to raise young increases with body size (Calder 1984), leaving large birds with less time in their annual cycle for other activities (Rohwer et al. 2011). In long-distance migrants, flight feather moult rarely overlaps with breeding or migration, but some species start moulting during the last part of the breeding season and stop before migration, resuming the moult in winter grounds (Herremans 2000; Chandler et al. 2010), whereas others only moult once in the wintering areas (Barshep et al. 2013). In contrast, sedentary large species can extend the time devoted to moult, but suspend moult in winter to save energy, in order to survive during adverse weather periods and to obtain enough reserves to start reproduction early (Zuberogoitia et al. 2013a). Hence, the more time spent rearing young, the less time for moult, and, reciprocally, a longer moult that clears worn feathers from the wing may make breeding in the next season impossible (Rohwer et al. 2011).

Non-breeding birds have more time available for moulting. However, for immature birds, time devoted to moult is constrained by their inexperience (a poor knowledge of the home range and thus decreased feeding efficiency). On the other hand, experienced breeders take advantage of their better knowledge of the territory, allowing them to obtain resources more efficiently than young birds (Espie et al. 2000; Daunt et al. 2007; Zuberogoitia et al. 2013b; Penteriani et al. 2013). Hence, adults optimize time and resources and, as a result, they can moult more flight feathers in a given moult period and quicker than inexperienced birds (Dietz et al. 2013; Zuberogoitia et al. 2013a).
In some of the biggest flying birds, such as vultures, condors, storks, and albatrosses, each moult cycle lasts more than a year, but may be interrupted during difficult periods, such as chick rearing, migration, or times of food shortage, such as midwinter in high latitudes or during extended droughts (Mundy 1982; Edelstam 1984; Clark 2004; Newton 2009). The moulting process places additional energy demands on birds (Hemborg and Lundberg 1998) in order to: (1) produce replacement plumage; (2) regulate body temperature while feather insulation is reduced; and (3) maintain efficient flight despite gaps in the wing due to dropped or growing feathers (Ginn and Melville 2000).

Feather growth rate in large birds is not much higher than in small birds, but because feathers are much longer, it takes longer to grow a long feather. Rohwer et al. (2009) suggest that feather growth rate does not increase proportional to feather size, but is constrained by one-dimensional follicle size. Moreover, many large birds that depend on flight for feeding during moult, shed only a part of their flight feathers annually and require two, and sometimes three, years to complete moult (Rohwer et al. 2009). They cannot tolerate large gaps in the wing, but can only tolerate one or two simultaneously growing feathers. The replacement of two or three adjacent remiges in quick succession can leave large gaps in the wings inhibiting flight, so most of these species have evolved strategies in which remiges at different locations are replaced at the same time, producing multiple smaller gaps while maintaining the wing's surface integrity and the bird's ability to fly (Pyle 2006). Moult duration is mainly determined by the number of simultaneously growing feathers (Rohwer and Rohwer 2013). This strategy for replacing remiges among large birds is known as "stepwise" or "serial" moult, and it is also called "Staffelmauser" (Stresemann and Stresemann 1966).

The Bearded Vulture, as other vultures, is a classic example of a bird that has a serial/stepwise moult (Staffelmauser; Houston 1975; Clark 2004; Zuberogoitia et al. 2013a). The moult pattern of the Bearded Vulture (Gypaetus barbatus) has received little attention despite its endangered status (see Margalida 2011). The species is currently listed as "priority species" in the conservation strategies of the European Union (Birds Directive, Annex I) and is listed as "endangered" in Spain (Antor et al. 2005). Hiraldo et al. (1979) documented a first approximation to the moult and later Adam and Llopis (2003) described the flight feather moult in captive birds and in free-ranging birds using photographs in flight. Later, Sesé (2011) published a summary of the moult pattern of Bearded Vultures. Therefore, the aim of this paper is to describe the moult pattern of the flight feathers of Bearded 
Vultures and analyse differences in the onset and duration of moult between age groups.

\section{Methods}

A total of 153 Bearded Vultures of different ages [87 nestlings, 34 2nd calendar year (cy), 18 subadults, and 14 adults] and both sexes ( 86 males, 58 females, nine unknown sex) were trapped, ringed, and tagged with wingtags from 1987 to 2014. Tags included an alphanumeric code allowing individual identification at distance with spotting scopes. This work took place as part of a long-term conservation and research program conducted by FCQ ("Fundación para la Conservación del Quebrantahuesos" in Spanish) in the central Pyrenees (Gil et al. 2010, 2014).

The number of trapped Bearded Vultures was limited due to the small population size of the species in the Pyrenees (i.e. 105 breeding units in Spain in 2010, Margalida 2011; Gil 2012). Moreover, the endangered status of this bird restricted the time devoted to obtain a correct moult pattern because we were not allowed to hold them long enough to score the moult of all trapped birds. Out of the 66 completed moult sheets, we used 24 in the analysis. The rest were excluded because we could not validate their moult sheets with adequate photos. Moult scores from six dead, marked birds of known age from wildlife rehabilitation centres were also obtained.

In addition, 94 moult cards were obtained from high definition (HD) and high quality pictures of wild birds taken by wildlife photographers (see Snyder et al. 1987, Fig. 1, see acknowledgements for photo credits). We compared series of photos of each individual and used individual marks in order to improve information about the moult.

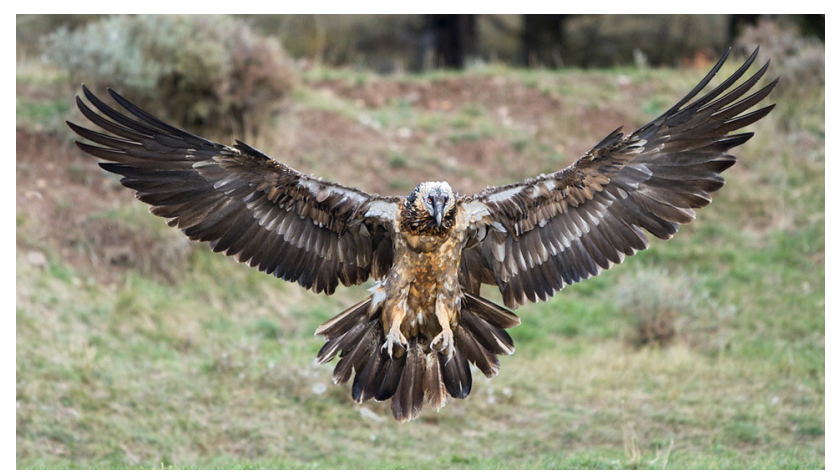

Fig. 1 Example of HD picture from which a moult pattern can be derived moult (picture by Bakartxo Aniz). This is a 4 cy bird recorded on 18th November 2011. This bird had completed the moult of all the flight feathers in 3 years. During 2011 it moulted P3, P4, P5, P9, and P10 from both wings, S1, S4, S7-13 from the right wing, S1, S7-10, S13-15 from the left wing and R3 and R5 from the tail feathers, including $\mathrm{R} 2$ right, which was growing
Summarizing, we used 124 complete moult sheets: 11 1 st cy, 25 2nd cy, 213 rd cy, 15 4th cy, 18 5th cy, and 34 adults.

\section{Number of feathers}

The birds in hand were inspected following a standardized protocol by one trained researcher (JAG). All birds were photographed, and these pictures and those of the other nonhandled birds were inspected by a second trained researcher (IZ, see Zuberogoitia et al. 2013a). We recorded a moult card for both wings of each individual, identifying feather generation by wear, shape, colour, age pattern, and growth of the remiges (i.e. primaries and secondaries) and rectrices. This gave us data for 10 primaries (PP) and 19-20 secondaries (SS) for each wing, and 12 rectrices (RR). For the moult analysis, we only included the first 16 SS because we observed that not all individuals had the expected $20 \mathrm{SS}$ (Adam and Llopis 2003): in four dead Bearded Vultures (two first calendar year birds and two adults) with no active moult in winter, the two juvenile birds had 19 SS, whilst the adults had 20 SS, confirmed by removing all feathers to count the insertion marks of SS in the ulna (forewing bone; Cieslak and Bolestaw 2006). These results suggest an individual differential number of SS, possibly due to the lack of one of the innermost SS. Primaries were numbered in descending order (from inside to outside), SS were numbered in ascending order (from outside to inside) and RR were numbered centrifugally (from the central feathers outwards).

\section{Moult score}

Following Ginn and Melville (2000) and Newton (2009) we followed a standard recording system according to the stage of growth of primaries and secondaries: old feathers were scored as 0 , fully grown new ones as 5 , and growing ones as 1-4 for intermediate stages of feather development. These individual moult scores were then summed to give an overall moult score between 0 and 50 (for $10 \mathrm{PP}$ ) and 0 and 80 (for 16 SS). Following Zuberogoitia et al. (2013a), feathers scored as 0 were also recorded as A (juvenile), $\mathrm{K}$ (moulted in the previous moult season), M (moulted 2 years ago), and $\mathrm{O}$ (moulted 3 years ago).

\section{The extent of the moult at different age stages}

In order to determine the extent of the moult for each age class, we used birds checked at the end of the year, with no active moult (some from the last days of November and December), from which we considered all the feathers scoring as "5" and birds from the first months of the year before the onset of the moult, considering all the feathers scoring as " $\mathrm{K}$ ". 


\section{Symmetry}

To calculate the symmetry of the moult process between wings, we superimposed both wings and compared each corresponding primary, secondary, and rectrix. We assigned " 1 " when both feathers were at the same moult level and " 0 " in those cases where the feathers were at a different stage. We then summed up the scores of PP and $\mathrm{SS}$ and calculated the percentage of symmetry for the flight feathers by comparing the sum to the total (see also Zuberogoitia et al. 2005).

\section{Timing of moult}

We analysed timing of primary and secondary moult using the models of Underhill and Zucchini (1988) and Underhill et al. (1990), implemented in the "moult" package (Erni et al. 2013) for $R$ ( $R$ Core Team 2014). These models give estimates of moult duration and average start date (from which average end date can be calculated) and also the standard deviation of the start date. Because the number of feathers moulted in a season differed between individuals, it was not possible to calculate the proportion of feather mass grown (the moult index used in the Underhill-Zucchini models) in the current season. For this reason we used the moult data type 1 (Underhill and Zucchini 1988), requiring only the information whether an individual has not yet started, is in moult, or has completed moult, coded as $0,0.5$, and 1 , respectively, only using the current year's moulting feathers for analyses. We used Julian day (January $1=1$ ) as time scale in the analyses and graphs. We classified individuals into three age groups: (1) Second cy: birds in the second calendar year (cy) during their first moulting season; (2) subadults: birds from 3cy to 5cy that are still non-breeders (López-López et al. 2013); and (3) adults: birds from 6cy onwards with adult plumage (Sesé 2011). Differences in start and duration of moult were expected between the age groups. This was tested by including age as a covariate on start and duration.

We ran three sets of models to estimate timing of moult in PP, SS, and PP and SS combined. We compared models using AIC, assuming models within two AIC units of the best model to have similar support as the best model (Burnham and Anderson 2002).

\section{Results}

\section{Modelling start and duration of moult}

According to Underhill and Zucchini's Models, the best model for PP and PP\&SS was M5 (Table 1). Models improved when "age" was considered as covariate. Start of moult and standard deviation in start clearly differed between age classes, and possibly duration differed between ages when considering PP and SS combined (model M4 was within two units of AIC of the best model M5). Most 2nd cy did not moult secondaries (Fig. 2). Therefore, for secondaries, we fitted the moult models to data including 2nd cy and then excluding 2nd cy. Excluding 2nd cy, the null model was within two AIC units of the best model (M2), showing that start and duration of moult of SS did not clearly differ between subadults and adults, although adults moulted on average more SS than subadults (Fig. 2).

Estimated average start of moult for subadult Bearded Vultures was 3rd of March [Table 2 (PP\&SS); Fig. 3], whereas adults started on average on 26th of April. Second cy birds delayed onset of moult until the 10th of May. The duration of moult also differed between age groups. The moult of PP finished before the SS (Table 2). In general, the moult lasted until November (Fig. 3). Subadults had the longest moult period (8 months) whilst 2 nd cy were moulting on average over a period of 6 months (Table 2).

\section{Moult pattern}

\section{Second calendar year (2cy)}

Bearded Vultures started moulting in their second cy. We did not find evidence of flight-feather moult in any of the 11 first cy Bearded Vultures analysed between the fledging season and the end of the year. There was no evidence of moult in 2cy Bearded Vultures before May $(n=6)$, and $50 \%$ of the analysed birds in May $(n=6)$ and $100 \%$ of birds in June $(n=5)$ had just dropped the P1. From then until December, 2cy Bearded Vultures moulted on average 4.32 inner primaries of each wing ( $\mathrm{SD}=1.25$; range 3-6; $n=25$, Fig. 4). When the fourth primary was moulted, by October, 2cy Bearded Vultures started to moult SS, normally S1, and rectrices, normally R1. Second cy Bearded Vultures moulted on average only $0.58 \mathrm{SS}(\mathrm{SD}=0.71$; range $0-2 ; n=26$, Fig. 4) of each wing and $0.56 \mathrm{RR}$ ( $\mathrm{SD}=0.71$; range $0-3 ; n=25$ ) of each side of the tail. The moulting process at this age showed a high degree of symmetry $(96.8 \%$ in PP, $99.5 \%$ in SS, and $96.67 \%$ in $\mathrm{RR})$.

\section{Third calendar year (3cy)}

Bearded Vultures continued moulting PP, beginning where they had left off in December of the previous year, mainly P5, P6, and P7. We also detected $35 \%$ of birds beginning a new wave from P1. During the third cy they replaced on average $3.75 \mathrm{PP}$ of each wing ( $\mathrm{SD}=0.97$; range $2-5 ; n=20$ ). The moult of $\mathrm{SS}$ and 
Table 1 Results of multimodel evaluation applied to the moult index of the Bearded Vulture

\begin{tabular}{llllllll}
\hline Model & Duration | start I SD & Type & $K$ & AIC PP & AIC SS & AIC SS* & AIC PP\&SS \\
\hline M1 & 1 | 1 | 1 & 1 & $3(2)$ & 139.4 & 206.0 & 142.3 & 136.0 \\
M2 & Age | 1 | 1 & 1 & $5(4)$ & 142.1 & 208.1 & $\mathbf{1 4 1 . 5}$ & 138.2 \\
M3 & Age | Age | 1 & 1 & $7(6)$ & 139.9 & $\mathbf{1 6 8 . 6}$ & 143.4 & 137.7 \\
M4 & Age | Age | Age & 1 & $9(6)$ & 136.9 & 171.2 & 144.2 & 132.6 \\
M5 & 1 | Age | Age & 1 & $7(6)$ & $\mathbf{1 3 4 . 2}$ & 169.0 & 144.0 & $\mathbf{1 3 2 . 0}$ \\
M6 & 1 | 1 | Age & 1 & $5(4)$ & 140.7 & 187.3 & 142.5 & 135.2 \\
\hline
\end{tabular}

Model ranking was assessed by Akaike information criteria (AIC). The models were fitted to four data sets: primaries (PP), secondaries (SS), secondaries without 2nd cy birds (SS*), and all remiges (PP\&SS). The best model is marked in bold. The number of parameters is different (in parentheses) for the model of SS* $S D$ standard deviation in start date, $K$ number of parameters
Fig. 2 Box plots of total moult scores for primaries and secondaries per age category. All sampled birds were considered for performing this plot
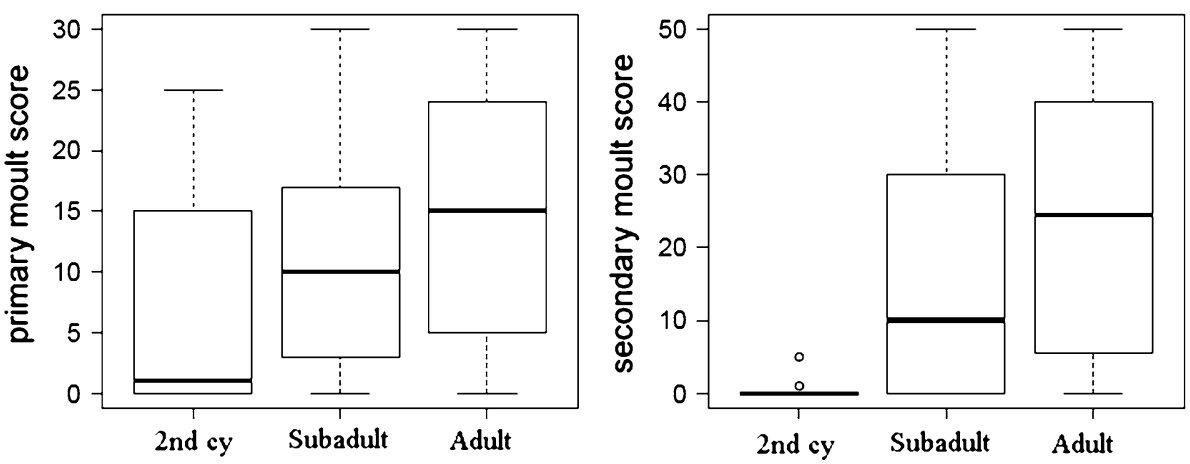

Table 2 Duration (days), start date, and standard deviation in start date (days) estimates for each age class obtained from the M4 models for primaries (PP) and primaries and secondaries (PP\&SS)

\begin{tabular}{llll}
\hline & Duration (SE) & Start (SE) & SD in start (SE) \\
\hline M4 PP & & & \\
2nd cy & $166.4(21.1)$ & May 17th (10.1) & $24.9(16.3)$ \\
Subadults & $184.7(30.4)$ & March 3rd (22.5) & $80.6(35.0)$ \\
Adults & $143.0(24.8)$ & April 27th (18.8) & $48.4(23.3)$ \\
M4 PP\&SS & & & \\
2nd cy & $184.2(13.2)$ & May 10th (6.3) & $13.2(10.1)$ \\
Subadults & $239.0(33.7)$ & March 6th (22.3) & $79.5(36.8)$ \\
Adults & $216.1(39.9)$ & April 26th (27.6) & $76.5(41.0)$ \\
\hline
\end{tabular}

$S E$ standard error

RR started 2 or 3 weeks after start of primary moult. During this period, 3cy birds moulted on average 5.78 $\mathrm{SS}(\mathrm{SD}=2.95$; range $1-11 ; n=19)$ and $2.55 \mathrm{RR}$ of each side of the tail $(\mathrm{SD}=1.25$, range $1-5, n=18)$. The moult of SS showed three foci: in S1, the starting focus, which continued inwards in an orderly manner, in S5 inwards, and in S15 towards both sides (Fig. 4). These foci were observed in birds that showed the neighbour feathers in sequential growing stages and different birds showing the overlapping sequence (one

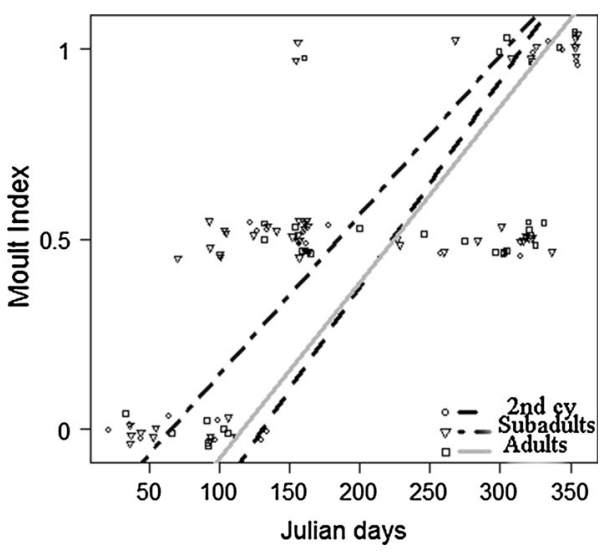

Fig. 3 Observed moult index ( 0 , not started; 0.5 , actively moulting; 1 , moult completed for season) for moult in primaries and secondaries of Bearded Vultures versus date (Julian days). The lines represent estimated moult trajectories of the three age classes obtained with model M4, starting at the mean start date, ending at mean end date

feather growing on the side of another new feather). Tail feather moult also showed different foci, starting in R1 outwards and following R6 inwards. We detected these two foci in rectrices active at the same time in some birds. The moulting process during the 3 cy still showed a high degree of symmetry in PP (92.5\%), but symmetry was lower than in 2nd cy birds in SS $(88.3 \%)$ and $\operatorname{RR}(82.5 \%)$. 
Fig. 4 Moult pattern of

Bearded Vultures. The pattern shows the most frequently moulted primaries and secondaries in second, third, fourth, and fifth calendar years. The feathers moulted in the current season are black, those moulted in the previous year are grey and those which have not been moulted are white. Moult foci and moult direction are indicated by arrows
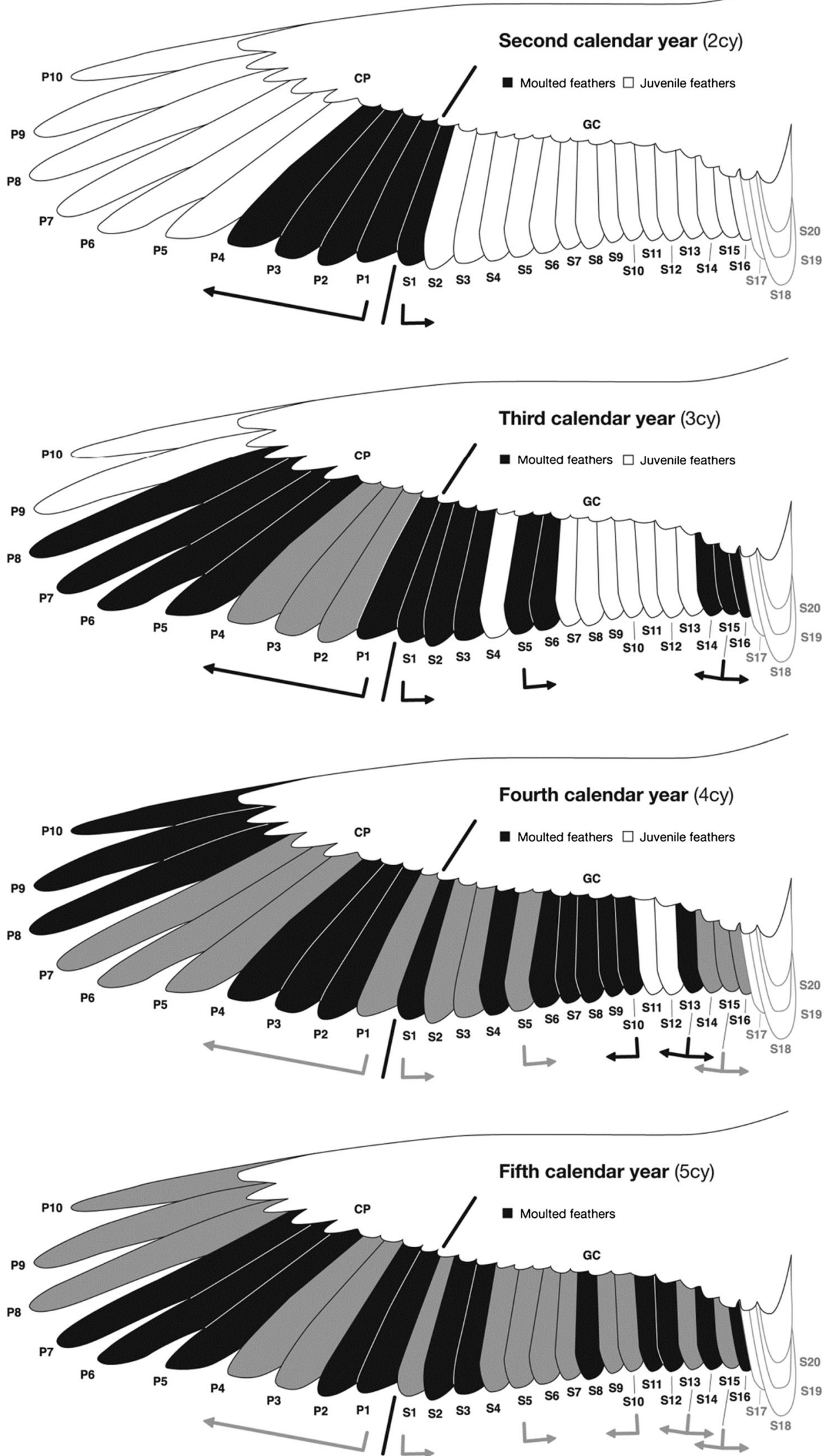


\section{Fourth calendar year (4cy)}

On average, $3.95 \mathrm{PP}(\mathrm{SD}=1.10$; range $3-7 ; n=20)$ of each wing were moulted, completing the first moult cycle (Fig. 4). During their fourth calendar year, Bearded Vultures moulted on average 7.05 SS $(\mathrm{SD}=2.01$; range 3-10; $n=19)$ and $2.5 \mathrm{RR}$ of each side of the tail $(\mathrm{SD}=0.95$, range $1-4, n=20$ ). The moult of SS followed the trajectory from the three above-mentioned foci, although two more foci may appear in S10 and S13. These new foci are a continuation of the moult wave. The same occurred in the tail feathers, filling the gaps and starting again. The moulting process during the 4th cy was less symmetrical in PP $(89.3 \%)$ than in the previous calendar year, but mainly in SS $(60.6 \%)$ and RR $(60.3 \%)$.

\section{Fifth calendar year (5cy)}

The moult followed where they had left off in winter of the previous year. Some birds (44.4\%) completed the second moult cycle of all $\mathrm{P}$ during this year, and all birds had advanced the second moult of SS, mainly in the three first foci (S1, S5, S15). In contrast, $29.4 \%$ of the birds still had juvenile SS (mainly S10, S11, and S12) in summer, at the middle of the moulting season. On average, $4.44 \mathrm{PP}$ $(\mathrm{SD}=0.88$; range $3-6 ; n=9), 7.11 \mathrm{SS} \quad(\mathrm{SD}=1.17$; range $6-9 ; n=9)$, and $3 \mathrm{RR}(\mathrm{SD}=0.71$; range $2-4$; $n=9$ ) were moulted in the fifth cy. The symmetry of moult in PP (82.29 \%) and SS (58.65\%) was similar to 4 cy birds, but less in RR (40.09\%).

\section{Moult in adults}

Adults moulted almost half of the flight feathers every year. On average, $4.8 \mathrm{PP}(\mathrm{SD}=0.79$; range $4-6 ; n=22)$, 8.2 SS (SD $=1.4 ;$ range $5-10 ; n=22)$, and $2.7 \mathrm{RR}$ ( $\mathrm{SD}=0.48$; range $2-3 ; n=22$ ) were moulted in adults. Moult did not follow an evident pattern at this age because, from the third moult onwards, the percentage of PP, SS and RR moulted (and consequently the start point of each moult) varied considerably among individuals and even between wings of the same bird. In fact, the symmetry between wings was on average $77.7 \%$ in PP, $50.6 \%$ in SS, and $52.3 \%$ in RR.

\section{Discussion}

Bearded Vultures fledge between late June and early August, and birds remain in their natal areas for the first 2 months after fledging, starting a post-fledging dependence period close to the natal areas until the onset of dispersal that coincides with the adult's next breeding season (López-López et al. 2014). During the following months, they will wander over extensive areas, and they must learn to become self-sufficient, acquire flight skills, find food resources, and exploit them efficiently. This period is, therefore, critical for survival (Margalida et al. 2013; Gil et al. 2014; López-López et al. 2014). Possibly as a consequence, we found that 2 nd cy birds delayed start of primary moult until late in May, and only few birds were able to moult secondaries during the last month before the end of the moulting season, in winter. During the second calendar year, they only moulted on average four inner primaries of each wing and rarely any secondaries. Possibly, only birds that had enough energy or could start sooner moulted the central pair of the tail feathers.

Feathers grown during the nestling period are of poorer quality than those of grown-up birds (Ginn and Melville 2000), so the wear of the feathers may be more pronounced until the individuals replace them. In the case of Bearded Vultures, juvenile secondaries are significantly longer than moulted ones, and these feathers show increasing degradation from 2 nd cy onwards, greatly contrasting with adult feathers, which are of much better quality. During the following years, birds should invest any surplus energy into moult in order to improve plumage quality. Remaining juvenile feathers are worn in the fourth calendar year. Insofar as birds have moulted their plumage during their first $4 \mathrm{cy}$, they will be in a better condition to overcome winter. Subadults (3-5 cy) started moult in March, considerably earlier than 2 nd cy birds and adults, although they showed high variability among individuals. As birds gain experience they can mobilize more energy to moult secondaries, increasing the percentage of secondaries moulted with age, whereas the number of primaries moulted per year remains the same or slightly increases with age. We would expect that non-breeding birds moult more feathers than breeders. The reduction in the number of feathers moulted after breeding has been proposed to reflect energy limitation due to reproductive activity (Pietiäinen et al. 1984); however, we did not have data on breeding status. In the case of subadults, foraging inexperience may be a limiting factor for the extent of moult.

The moult pattern of Bearded Vultures is characterised by the replacement of few flight feathers during the first moult periods. Following the usual moult pattern in large soaring raptors (i.e. moult waves; Edelstam 1984; Clark 2004), the innermost primaries and neighbouring secondaries tend to be replaced more often than others (Houston 1975; Mundy 1982; Snyder et al. 1987; Pyle 2005; Zuberogoitia et al. 2013a). In fact, our results (Fig. 4) showed that before outer primaries or some secondaries of the fourth and fifth foci (S10 and S13) were moulted for the first time, birds had replaced inner primaries and secondaries for the second time. Langston and Rohwer (1995) 
suggested that Laysan (Phoebastria immutabilis) and Black-footed Albatrosses (Pygathrix nigripes) more often replace those primaries that drag on the sand of the atolls where the birds breed and become severely abraded. In the same line, Brommer et al. (2003) showed that Ural Owls (Strix uralensis) more often replace outer primaries, suggesting that the allocation of position-specific energetic costs may benefit large birds. The moult pattern of subadult Bearded Vultures reflects the importance of the good maintenance of inner primaries and secondaries for soaring and gliding.

Bearded Vultures reach definitive plumage in their 6th calendar year (Sesé 2011), approximately the same age at which they start to establish a territory (López-López et al. 2014). This, in turn, reflects the importance of the relationship between the acquisition of definitive plumage, the reach of sexual maturity and the settlement in a breeding territory (Rohwer et al. 2011).

Adults started moult 1.5 months later than subadults, possibly due to breeding requirements. The onset of moult synchronizes with the presence of 1-month-old nestlings (see Margalida et al. 2005). For example, Rohwer et al. (2011) showed that the Black-footed Albatross's moult is so time-constrained by reproduction that some individuals fail to replace all their flight feathers every 2 years. This resulted in reduced breeding performance due to skipping behaviour or breeding with worn feathers. Moult in birds that overlap moult and breeding was found to be slow and protracted (Foster 1975; Rohwer et al. 2009), confirming the high cost of replacing flight feathers while breeding.

Most adults moulted all flight feathers in 2 years. They started a bit later than subadults, moulted more feathers, but duration was almost the same. Our findings correspond to those of Dietz et al. (2013) who showed that moult of adult Red Knots (Calidris canutus) is seriously time-constrained by reproduction and that adults moult later but faster than second calendar year birds.

Adult Bearded Vultures show a high degree of asymmetry, mainly in secondaries and tail feathers. According to Rohwer et al. (2011) and Zuberogoitia et al. (2013a) some mechanism may enable them to replace feathers that are damaged or unusually worn, regardless of the biennial cycle. However, asymmetry appears to have negative consequences for survival (Brommer et al. 2003). In agreement with Brommer et al. (2003), asymmetry in primaries, which are used for flight propulsion (Hickman et al. 1993), appears to be less than the asymmetry in secondaries, which are used for lift.

Acknowledgments This paper has been developed under the agreement signed by the Foundation for the Conservation of the Bearded Vulture (FCQ), Aragón regional government and the Spanish Ministry of Environment, under the actions of the Bearded Vulture Recovery Plan in Aragón and the Bearded Vulture Reintroduction
Program in Picos de Europa. We are indebted to the Departamento de Agricultura, Ganadería y Medio Ambiente (Aragón regional government), European Union (LIFE 1998-2006, and INTERREG IIIA 2002-2006 programs), MIMAM (Spain), Guardia Civil (GREIM), Aragón Forest Rangers (APN), Wildlife Rehabilitation Centre at La Alfranca (Zaragoza), LVFS, IREC-CSIC, EBD-CSIC, SEO/BirdLife, "Aragón” Ringing Group, Trango, Zeiss and Land Rover. Thanks to J Guiral, J Insausti and M. Alcantara. G. González, I. Otra, J. Serra, J. Sánchez, J. Marti, S. Marcedos, J. Vecino, D. Forsman, for sharing with us their picture collections of Bearded Vultures. L Palomares helped us drawing the Fig. 4. Special thanks are due to all the members of the FCQ and particularly to O Díez, G Baguena, L Lorente, R Antor, G Chéliz, JC Ascaso and JC Gonzalez. Two anonymous reviewers provided helpful comments on the manuscript. This paper complies with the current laws in Spain. The authors declare that no conflict of interest exists.

\section{References}

Adam A, Llopis A (2003) The Bearded vulture (Gypaetus barbatus): age features and moult process. Taller de Ecología—Ecologistas en Acción, Linares, Madrid

Antor RJ, Margalida A, Heredia R (2005) Quebrantahuesos. Gypaetus barbatus. In: Madroño A, González C, Atienza JC (eds) Libro rojo de las aves de España. Dirección General para la Biodiversidad-SEO/BirdLife, Madrid, pp 125-129

Barshep Y, Minton CDT, Underhill LG, Erni B, Tomkovich P (2013) Flexibility and constraints in the moult schedule of long-distance migratory shorebirds: causes and consequences. Ecol Evol 3(7):1967-1976

Brommer JE, Pihlajamäki O, Kolunen H, Pietiäinen H (2003) Lifehistory consequences of partial-moult asymmetry. J Anim Ecol 72:1057-1063

Burnham KP, Anderson (2002) Model selection and multimodel inference. A practical information-theoretic approach, 2nd edn. Springer, New York

Calder WAI (1984) Size, function, and life history. Harvard University Press, Cambridge

Chandler RM, Pyle P, Flannery ME, Long DJ, Howell SG (2010) Flight feather molt of turkey vultures. Wilson J Ornithol 122:254-260

Cieslak M, Bolestaw D (2006) Feathers identification for bird conservation. Natura Publishing House, Warsaw

Clark WS (2004) Wave molt of the primaries of Accipitrid raptors, and its use in ageing. In: Chancellor RD, Meyburg B-U (eds) Raptors worldwide: proceedings of the VI world conference on birds of prey. World Working Group on Birds of Prey, Berlin, pp 795-804

Daunt F, Wanless S, Harris MP, Money L, Monaghan P (2007) Older and wiser: improvements in breeding success are linked to better foraging performance in European shags. Funct Ecol 21:561-567

Dietz MW, Rogers KG, Piersma T (2013) When the seasons don't fit: speedy Molt as a routine carry-over cost of reproduction. PLoS One 8(1):e53890. doi:10.1371/journal.pone.0053890

Edelstam C (1984) Patterns of moult in large birds of prey. Ann Zool Fenn 21:271-276

Erni B, Oschadleus HD, Bonnevie B, Altwegg R, Underhill LG (2013) Moult: an R-package to analyse moult in birds. J Stat Soft 52:1-23

Espie RHM, Oliphant LW, James PC, Warkentin IG, Lieske DJ (2000) Age-dependent breeding performance in Merlins (Falco columbarius). Ecology 81:3404-3415

Foster MS (1975) The overlap of molting and breeding in some tropical birds. Condor 77:304-314 
Gil JA (2012). Quebrantahuesos, Gypaetus barbatus. In: SEO/ BirdLife. Atlas de las aves en invierno en España 2007-2010. Ministerio de Agricultura, Alimentación y Medio AmbienteSEO/BirdLife, Madrid, pp166-167

Gil JA, Díez O, Báguena G, Lorente L, Pérez C, Losada JA, Alcántara M (2010) Juvenile dispersal of the Bearded vulture (Gypaetus barbatus) in the Pyrenees (Spain-France). Fundación para la Conservación del Quebrantahuesos (FCQ), Zaragoza

Gil JA, Báguena G, Sánchez-Castilla E, Antor RJ, Alcántara M, López-López P (2014) Home range and movements of nonbreeding Bearded vultures tracked by satellite telemetry in the Pyrenees. Ardeola 61(2):379-387

Ginn HB, Melville DS (2000) Moult in birds. BTO Guide 19. In: Norwich UK, Hammer O (eds) 2011. PAST PAleontological STAtistics. Version 2.1. reference manual. Natural History Museum, University of Oslo, Oslo

Hedenström A (2006) Scaling of migration and the annual cycle of birds. Ardea 94:399-408

Hemborg C, Lundberg A (1998) Costs of overlapping reproduction and moult in passerine birds: an experiment with the Pied Flycatcher. Behav Ecol Sociob 43:19-23

Herremans M (2000) The "chaotic" flight feather moult of the Steppe buzzard buteo buteo vulpinus. Bird Study 47:332-343

Hickman CP, Roberts LS, Larson A (1993) Integrated principles of zoology. Mosby, St Louis

Hiraldo F, Delibes M, Calderón J (1979) El Quebrantahuesos Gypaetus barbatus (L.). Sistemática, taxonomía, biología, distribución y protección. Monografías 22. Instituto Nacional para la Conservación de la Naturaleza, Madrid

Houston DC (1975) The moult of the white-backed and Rüppell's Griffon vultures Gyps africanus and G. rueppellii. Ibis 117:474-488

Langston NE, Rohwer S (1995) Unusual patterns of incomplete primary molt in laysan and black-footed albatrosses. Condor 97:1-19

López-López P, Zuberogoitia I, Alcantara M, Gil JA (2013) Philopatry, natal dispersal, first settlement and age of first breeding of Bearded Vultures Gypaetus barbatus in central Pyrenees. Bird Study 60:555-560

López-López P, Gil JA, Alcántara M (2014) Post-fledging dependence period and onset of natal dispersal in Bearded vultures (Gypaetus barbatus) : new insights from GPS satellite telemetry. J Raptor Res 48:173-181

Margalida A (2011). Quebrantahuesos-Gypaetus barbatus. In: Salvador A, Bautista LM (eds) Enciclopedia Virtual de los Vertebrados Españoles. Museo Nacional de Ciencias Naturales, Madrid. http://www.vertebradosibericos.org/

Margalida A, García D, Bertran J, Heredia R (2005) Biología de la reproducción del quebrantahuesos en los Pirineos. In: Margalida A, Heredia R (eds) Biología de la Conservación del Quebrantahuesos (Gypaetus barbatus) en España. Serie técnica, Organismo Autónomo Parques Nacionales, Ministerio de Medio Ambiente, Madrid, pp 279-304
Margalida A, Carrete M, Hegglin D, Serrano D, Arenas R, Donázar JA (2013) Uneven large-scale movement patterns in wild and reintroduced pre-adult bearded vultures: conservation implications. PLoS One 8(6):e65857. doi:10.1371/journal.pone.0065857

Mundy PJ (1982) The comparative biology of southern African vultures. Vulture Study Group, Johannesburg

Newton I (2009) Moult plumage. Ring Migrat 24:220-226

Penteriani V, Rutz C, Kenward R (2013) Hunting behaviour and breeding performance of northern goshawks accipiter gentilis, in relation to resource availability, sex, age and morphology. Naturwissenschaften 100:935-942

Pietiäinen H, Saurola P, Kolunen H (1984) The reproductive constraints on moult in the ural owl strix uralensis. Ann Zool Fenn 21:277-281

Pyle P (2005) Remigial molt patterns in North American falconiformes as related to age, sex, breeding status, and life-history strategies. Condor 107:823-834

Pyle P (2006) Staffelmauser and other adaptative strategies for wing molt in larger birds. Western Birds 37:179-185

R Core Team (2014) R: a language and environment for statistical computing. R Foundation for Statistical Computing, Vienna, Austria. http://www.R-project.org/

Rohwer VG, Rohwer S (2013) How do birds adjust the time required to replace their flight feathers? Auk 130:699-707

Rohwer S, Ricklefs RE, Rohwer VG, Copple MM (2009) Allometry of the duration of flight feather molt in birds. PLoS Biol 7(6):e1000132. doi:10.1371/journal.pbio.1000132

Rohwer S, Viggiano A, Marzluff JM (2011) Reciprocal tradeoffs between molt and breeding in albatrosses. Condor 113:61-70

Sesé JA (2011) Los plumajes del Quebrantahuesos. In: Lacasa M (ed) El libro de las rapaces. Photodigiscoping S.C.P, Barcelona, pp 10-25

Snyder NFR, Johnson EV, Clendenen DA (1987) Primary molt of California Condors. Condor 89:468-485

Stresemann E, Stresemann V (1966) Die Mauser der Vögel. J für Ornitholo 107:1-448

Underhill LG, Zucchini W (1988) A model for avian primary moult. Ibis 130:358-372

Underhill LG, Zucchini W, Summers RW (1990) A model for avian primary moult-data types based on migration strategies and an example using the redshank Tringa totanus. Ibis 132:118-123

Zuberogoitia I, Martínez JA, Zabala J, Martínez JE, Castillo I, Hidalgo S (2005) Sexing, ageing and moult of common buzzards buteo buteo in a southern Europe area. Ring Migrat 22:153-158

Zuberogoitia I, De la Puente J, Elorriaga J, Alonso R, Palomares LE, Martínez JE (2013a) The flight feathers molt of griffon vultures Gyps fulvus and associated biological consequences. J Rapt Res 47(3):292-303

Zuberogoitia I, González-Oreja JA, Martínez JE, Zabala J, Gómez I, López-López P (2013b) Foraging movements of Eurasian Griffon Vultures (Gyps fulvus): implications for supplementary feeding management. European J Wildl Res 59:421-429 